\title{
Treatment of Lower Pole Renal Stones-Extracorporeal Shock Wave Lithotripsy vs Endourology A literature review
}

\author{
LAURIAN STEFAN MAXIM ${ }^{1,2 *}$, SORIN LUPU ${ }^{1}$, RADU BARBULESCU ${ }^{1}$, ALEXANDRU BANUTA ${ }^{1}$, ALEXANDRU LACULICEANU ${ }^{1}$, \\ ADRIAN BRANZA ${ }^{1}$, CAMELA CORNELIA SCARNECIU ${ }^{1,2}$, CALIN PAVEL COBELSCHI ${ }^{3}$, CATALIN MISARCA ${ }^{3}$, IOAN SCARNECIU1,2 \\ ${ }^{1}$ Clinical Emergency County Hospital Brasov, Clinic of Urology, 25-27 th Bucuresti Road, 500326, Brasov, Romania \\ ${ }^{2}$ University of Medicine and Pharmacy Transilvania, 56th Nicolae Balcescu Str., 500019,Brasov, Romania \\ ${ }^{3}$ Clinical Emergency County Hospital, Surgery Department, 25-27th Bucuresti Road, 500326, Brasov, Romania
}

\begin{abstract}
Urolithiasis is a subject of great interest in the urological world nowadays, due to the increasing incidence of the disease caused by the metabolic disorders that arise from the modern lifestyle, which is often not beneficial to the human body. Also, pathology is intensely debated because its treatment involves significant costs for society. The present article aims to compare the endourological treatment methods with extracorporeal shock waves lithotripsy for lower calyceal lithiasis, which is an intensely debated topic, and the opinions are divided regarding the choice of the optimal method for the management of this pathology. The location of the stone at the level of the inferior calyceal group implies a difficult approach regardless of the chosen treatment method, butalso a poor excretion of the remaining fragments, frequently encountering a lower stone-free rate. Thus, the treatment methods were compared, taking into account the anatomic factors, the size of the stone, its hardness, the risk of the occurrence of intraoperative or postoperative complications, the necessity of a possible reintervention and the duration of the intervention. Last but not least, the patient's preference must be taken into account, obviously, after a physician-patient dialogue explaining to the patient the individual treatment, and being guided to the optimal therapy for the patient.
\end{abstract}

Keywords: urinarylithiasis, lower pole stones, extracorporeal shockwave lithotripsy, flexible ureterorenoscopy, percutaneous nephrolithotomy.

Urinary lithiasis, known since antiquity, is a common disorder that is nowadays a topic of great interest in the current medical world. This is explained by the increasing incidence of pathology over the last decades, especially in developed or developing countries, with significant costs for society. This explains the major efforts in terms of the evolution of modern treatment for urolithiasis, but also of prophylaxis. The probable cause of this phenomenon is represented by the modern lifestyle, butalso by the increase of global obesity as well as the presence of other pathologies that associate with a metabolic imbalance [1-4]. Another mechanism responsible for the lithogenesis process is urinary stasis, secondary to obstructive pathologies such as benign or malignant prostatic hyperplasia [5-8], urethral stricture, ureteral stenosis, nearby compression, retroperitoneal tumors that may partially compress the ureteres, leading to urinary stasis $[9,10]$. Undiagnosed or neglected, this pathology can lead to recurrent urinary tract infections and even to urinary sepsis [11-16]. Patients with diabetes and urinary lithiasis, as well as those with different pathologies that associate immunodeficiency, and even pregnancy, present higher risks of developing urinary sepsis when compared with lithiasic patients, but without the previously mentioned pathologies [17-25]. Another serious complications that could appear over the years in lithiasic patients is chronic kidney disease $[26,27]$. Often, these patients will undergo chronic hemodialysis $[28,29]$. These patients that will undergo hemodialysis will unavoidable develop cardiovascular complications, such as high blood pressure and heartfailure [30,31]. Over time, it has been found that within 20 years, urinary lithiasis relapses in about two-thirds of patients, with men more likely to develop pathology (about 12\%), compared to women who are affected by about 5\% [32].

The recent increase in the prevalence of this disease can be explained by the emergence of modern imaging diagnostic methods and devices, but also by incidental discovery of asymptomatic kidney lithiasis. Imaging has an important role both in the diagnosis of renal lithiasis and in the long-term follow-up of the patient with reno-ureteral lithiasis. Computed tomography (CT) without contrast is the gold standard for the diagnosis of kidney and ureteral stones with high specificity and sensitivity (> 96\%, respectively $>95 \%$ ), with the advantage of identifying other pathologies that can mimic renal colic and avoid use contrast substance (1). The non-contrast CT scan provides information on both urinary morphology and stone size, shape, density, location or skin-to-stone distance [33].

There are currently many methods of treatment of urolithiasis, including conservative management, extracorporeal shock waves lithotripsy, endourological surgical treatment, laparoscopic surgery or open approach. The choice of ideal renal lithiasis treatment is based on several criteria, including size, location, or density of the stone.

Currently, according to the European Association of Urology (EAU) Guideline, the renal lithiasis treatment is based on PNL for stones larger than $20 \mathrm{~mm}$, ESWL or endourological surgery for $10-20 \mathrm{~mm}$ stones, and ESWL as a method of choice for stones $<10 \mathrm{~mm}$ [34]. Regarding the treatment of renal lithiasis located in the lower renal pole, there have been many debates, but no consensus has been reached. The EAU Guidelines recommend as treatment methods for inferior kidney poles with dimensions between 10-20 mm, ESWL or endourology depending on favorable or unfavorable factors for ESWL. 


\section{Experimental part \\ Method}

The treatment by extracorporeal shock waves lithotripsy in most cases is the first intention due to noninvasive procedure, lack of hospitalization or lack of anesthesia, the success rate being reported in the literature at $80 \%$ $90 \%[32,33]$.

Another more effective method for the treatment of renal lithiasis is percutaneous nephrolithotomy (PNL), a more invasive method with the disadvantage of increased morbidity, risk of bleeding, urinary extravasation, long hospitalization, and an increased risk of injuries to neighboring organs, but with the benefit of a clearance of the stones of over $90 \%[35,36]$.

Despite the increased success rate, the method is not preferred for patients with morbid obesity or severe coagulopathies, so they are opting for much less invasive methods such as retrograde intrarenal surgery, a very effective method especially in the management of renal calculi located at the lower pole.

Retrograde intrarenal surgery (RIRS) or flexible ureteroscopy is a non-invasive method that has become increasingly known and used over the past decade and can be used both in the diagnosis and treatment of renal ureteral lithiasis and other pathologies such as highuretheral stenosis, etc. The advantages of ureteroscopy that make this method more preferable by urologists refer to much lesser risks than percutaneous nephrolithotomy, with a roughly equivalent rate of stone-free: from $77 \%$ to $>90 \%$ for renal stones (other than those located at the lower pole) and $62 \%$ - $85 \%$ for the treatment of lower calyceal lithiasis [37-41].

\section{Aim}

To examine previous reports and compare ESWL with endourological treatmentfor inferior pole stones, depending on anatomical factors, stone size and hardness, the risk of intraoperative and postoperative complications, the need for a possible reintervention, and the duration of the intervention.

Reports of urinary lithiasis were reviewed, assessing publications from 1992 to 2015.

\section{Results and discussions}

The treatment of urinary lithiasis has changed a lot, requiring a less invasive treatment such as ESWL, used in $80-90 \%$ of cases of renal and ureteral lithiasis due to its association with a low rate of complications; many experimental studies regarding the pathologies of urinary apparatus brings a lot of information in the field [42-49]. Also, flexible ureteroscopy and percutaneous nephrolithotomy have become more prominent than open surgery, which is nowadays used in less than $5 \%$ of cases of urolithiasis [50,51].

In a study by Sampaio et al, it has been observed that the infundibulopelvic angle (IPA), the lower infundibulum diameter and the arrangement of calyx have an important role in the lower calice system drainage [52]. Subsequently, the same authors have demonstrated, after evaluating the radiological measurements, that these values are of particular importance in eliminating the remaining lithiasis fragments after extracorporeal shock waves lithotripsy [53]. A study by Ruggera et al, on a batch of 107 patients, demonstrated that those with IPA, infundibular length (IL), infundibular width (IW) with mean values of 54, 34 and $5.5 \mathrm{~mm}$ respectively, remained with residual fragments at three months post treatment, unlike patients with IPA, IL, IW of 65,32 and $7 \mathrm{~mm}$ respectively, where success was
$100 \%$ [54]. In these cases, when patients remain with ESWL residual lithiasis, other adjuvant treatment methods such as placing the patient in the Trendelenburg position during the ESWL procedure [55] or percutaneous or retrograde irrigation with litholytic agents [56,57].

For flexible ureteroscopy, infundibulopelvic angle or infundibular length are factors that do not influence the success of the method, while the $\geq 5 \mathrm{~mm}$ width is a positive prognostic factor [58]. On the other hand, in a Resorlu study, it has been shown that although the anatomy of the pyelocaliceal system does not influence surgical maneuver, a possible unfavorable factor for the elimination of overlapping fragments is, as with ESWL, the infundibulopelvic angle [59].

Comparing ESWL alone and ESWL therapy with adjuvant treatment (consisting of PDI therapy: mechanical percussion, diuresis and inversion), it was concluded that adjuvant treatment in ESWL for lower renal pole stones is beneficial and favors the elimination of lithiasis fragments [60].

Regarding the comparison of ESWL with flexible ureteroscopy, URS has a higher stone-free rate than ESWL, in the case of stones $<10 \mathrm{~mm}[61,62]$ and $10-20 \mathrm{~mm}$ $[59,60]$. In one study, conducted by Kumar A et al, the efficacy of ESWL was similar to URS, but for the treatment of proximal ureteral lithiasis $<10 \mathrm{~mm}$ [63].

Comparing ESWL with PNL, in a study conducted by Albala DM on a group of 128 patients with inferior calyceal renal lithiasis, there was a remarkable efficacy of PNL treatment with a 95\% clearance at 3 months postoperatively compared to the group of patients treated with ESWL (37\%) [35]. Therefore, it is preferable for the management of lower pole stones larger than $14 \mathrm{~mm}$ to guide the patient towards PNL at the expense of ESWL, especially since percutaneous nephrolithotomy has seen a lower injury to the parenchyma compared to ESWL $[64,65]$.

Regarding the side effects that may occur after ESWL, there are renal colic or steinstrasse, fever complications that can be avoided by mounting a ureteral stent before initiating ESWL sessions [66]. Also, ureteral stent placement has adverse effects such as dysuria, urinary frequency, urgency and macroscopic haematuria, all of which lead to a decrease in the patient's quality of life $[67,68]$. In the case of difficult catheterization, injuries to the ureterovesical junction can occur, resulting in vesicoureteral reflux and even acute reflux pyelonephritis [69].

Endourological maneuvers may cause more frequently cardiovascular complications (retroperitoneal hematoma) or iatrogenic ureteral perforations $[70,71]$. Following treatment of lower pole lithiasis by flexible ureteroscopy or percutaneous nephrolithotomy, convalescence is higher than ESWL [62]. Another disadvantage of flexible ureteroscopy is the need for fragile and expensive instruments, requiring frequent repair due to the rapidly degrading active deflection mechanism [71].

Comparing RIRS with PNL from the point of view of complications, the former is preferred as much as it offers an equally high rate of stone-free [37].

In terms of operating time, ESWL has an advantage, with an average operating time of approximately $44.7 \mathrm{~min}$ compared to 106.2 minutes for URS or 84.6 minutes for PNL $[71,72]$. Also, in the favor of extracorporeal lithotripsy is the rapid learning curve $[73,74]$.

Besides the listed criteria, lower pole lithiasis management should be carefully chosen based on patient's preference and given the possibility to choose the therapy (drug, surgical, etc.) that would benefit him [75-77]. 


\section{Conclusions}

Treatment of lower-pole stones is a widely discussed topic at international level, with the aim of choosing the most effective method of treatment for the patient, while providing the safety of the treating physician. A variety of factors such as urinary tract anatomy, calculus size, stonefree rate after procedure, need for reintervention, should be considered to choose the optimal method of treatment of lower renal pole lithiasis.

Regarding the effectiveness of the three treatment methods, it is very obvious that endourological therapy (PNL and RIRS) has a much higher rate of stone-free at 3 months and a lower rate of reintervention compared to ESWL, but for lower-pole stones with dimensions $<10 \mathrm{~mm}$, ideal management is represented by ESWL together with adjuvant therapy, both in terms of clearance of renal calculi, as well as in terms of operating time and side effects. Thus, we can state that ESWL is the first intention method for managing small-sized calculi. It was also found that, between ESWL and flexible ureteroscopy, there were no significant differences in the stone-free rate at an infundibulopelvic angle $>40$ degrees. Regarding the rate of post-procedural complications, it is clear that URS and PNL being invasive treatment methods have a higher risk of developing complications. In the case of flexible ureteroscopy, the incidence of complications is insignificantly higher compared to ESWL.

Finally, it can be concluded that each treatment method has its advantages, but the result depends on choosing the optimal method for each case.

\section{Abbreviations \\ $C T$ : Computed tomography \\ EAU : European Association of Urology \\ PNL : percutaneous nephrolithotomy \\ ESWL : extracorporeal shock waves lithotripsy \\ RIRS : retrograde intrarenal surgery \\ IPA : infundibulo-pelvic angle \\ IL : infundibular length \\ IW : infundibular width \\ URS : ureterorenoscopy}

\section{References}

1.ANDRABI, Y., PATINO, M., DAS, C.J., et al. Indian J Urol, 31, no. 3, 2015, p. 185-193.

2.DIACONU, C., NASTASA, A., ZAKI, A.R., ARSALAN, M. 2nd International Conference on Interdisciplinary Management of Diabetes Mellitus and its Complications, INTERDIAB 2016 Proceedings, Editura Niculescu, p. 201-210.

3.GRADISTEANU, GP., STOICA, R.A., PETCU, .L, et al. J ournal Of Mind And Medical Sciences, 6, no.1, 2019, p.130-136.

4.PANTEA-STOIAN, A, STEFAN, D.S., DITU, G, et al.,Conference: 2nd International Confeence on Interdisciplinary Management of Diabetes Mellitus and its Complications, INTERDIAB 2016, p.353-362.

5.MARCU, D., SPINU, D., MISCHIANU, D., SOCEA, B., OPREA, I., BRATU, O. Rom J Mil Med, 120, no. 3, 2017, p. $39-42$.

6.CIUCA, G.A., BRATU, O., SPINU, D., DINU, M., FARCAS, C., RADULESCU, A., POPESCU, R., MARCU, D., MISCHIANU, D., ARMEAN, P. Rom J Mil Med, 119, no. 2, 2016, p. 12-16.

7.BRATU, O., SPINU, D., OPREA, I., POPESCU, R., MARCU, D., FARCAS, C., DINU, M., MISCHIANU, D. Rom J Mil Med, 118, no. 3, 2015, p. 23-25. 8.BRATU, O., MARCU, D., SPINU, D., RADULESCU, A., OPREA, I., MISCHIANU, D. Rom J Mil Med, 118, no. 3, 2015, p. 40-44.

9.CONSTANTINOIU, S., BARLA, R., IOSIF, C., COCIU, L., GINDEA, C., HOARA, P., BRATU, O., RUSITORU, L. Chirurgia (Bucur), 104, no. 3, 2009, p. 363-367.

10.RADAVOI, G.D., PRICOP, C., J INGA, V., etal. Rom J Morphol Embriol, 57, no. 2, 2016, p. 467-475.
11.RADULESCU, A., MADAN, V., AUNGURENCI, A., BRATU, O., FARCAS, C., DINU, M., MISCHIANU, D. Rom J Mil Med, 118, no. 3, 2015, p. $20-22$. 12.DIACONU, C., BALACEANU, A., MOROSAN, E. Farmacia, 63, no. 6, 2015, p. 811-815.

13.SPINU, D., BRATU, O., POPESCU, R., MARCU, D., RADULESCU, A., MISCHIANU, D. Rom J Mil Med, 118, no. 3, 2015, p. 12-15.

14.BODEAN, O., BRATU, O., BOHILTEA, R., et al. Rev Chim (Bucharest), 69, no. 6, 2018, p. 1411-1415.

15.SOCEA, L.I., VISAN, D.C., BARBUCEANU, S.F., APOSTOL, T.V., BRATU, O.G., SOCEA, B. Rev Chim (Bucharest), 69, no. 4, 2018, p. 795-797.

16.TICA, O.A., TICA, O., ANTAL, L., HATOS, A., POPESCU, M.I., PANTEA STOIAN, A., BRATU, O.G., GAMAN, M.A., PITURU, S.M., DIACONU, C.C. Farmacia, 66, no. 6, 2018, p. 972-976.

17.DIACONU, C., BALACEANU, A., BARTOS, D. Central European Journal of Medicine, 8, no. 5, 2013, p. 548-552.

18.SPINU, A.D., MARCU, R.D., SOCEA, B., et al. Rev Chim (Bucharest), 69, no. 8, 2018, p. 2061-2063.

19.SURCEL, M., HUICA, R.I., MUNTEANU, A.N., ISVORANU, G., PIRVU, I.R., CIOTARU, D., CONSTANTIN, C., BRATU, O., CARUNTU, C., NEAGU, M., URSACIUC, C. Experimental and therapeutic medicine, 17, no. 2, 2019, p. 1030-1038.

20.MEHEDINTU, C., ANTONOVICI, M., BRINDUSE, L., BRATILA, E., STANCULESCU, R., BERCEANU, C., BRATU, O., PITURU, S., ONOFRIESCU, M., MATASARIU, D.R. Rev Chim (Bucharest), 69, no. 3, 2018, p. 581-584.

21.PALLAG, A., ROSCA, E., TIT, D.M., MUTIU, G., BUNGAU, S.G., POP, O.L., Rom. J. Morphol. Embriol., 56, no. 3, 2015, p. 1103.

22.ENDRES, L., TIT, D.M., BUNGAU, S., CIOCA, G., ABDEL-DAIM, M., BUHAS, C., POP, O., SAVA, C., Rev. Chim.-Bucharest, 69, no. 12, 2018, p. 3675.

23.ELIAN, V., CIOCA, G., PANTEA STOIAN A., et al.,Conference: 1st International Conference on Interdisciplinary Management of Diabetes Mellitus and its Complications (INTERDIAB) INTERDISCIPLINARY APPROACHESIN DIABETIC CHRONIC KIDNEY DISEASE, 2015, p.48-52. 24.ELIAN, V, CONSTANTIN, C., STOIAN, ANCA, et al.,Conference: 1st International Conference on Interdisciplinary Management of Diabetes Mellitus and its Complications (INTERDIAB) INTERDISCIPLINARY APPROACHESIN DIABETIC CHRONIC KIDNEY DISEASE, 2015, p.53-58. 25.PANTEA-STOIAN, A.,STERIADE, O., ELIAN, V., et al.Conference: 1st International Conference on Interdisciplinary Management of Diabetes Mellitus and its Complications (INTERDIAB) INTERDISCIPLINARY APPROACHES IN DIABETIC CHRONIC KIDNEY DISEASE,2015,p. 256261.

26.PERIDE, I., CHECHERITA, I.A., CIOCALTEU, A.L., LASCAR, I. Chirurgia (Bucur), 106, no. 1, 2011, p. 83-89.

27.POPESCU, R., BRATU, O., SPINU, D., MARCU, D., FARCAS, C., DINU, M., MISCHIANU, D. Rom J Mil Med, 118, no. 3, 2015, p. 16-19.

28.CHECHERITA, I.A., PERIDE, I., NICULAE, A., et al. Econ Comput Econ Cyb., 50, no. 1, 2016, p. 291-310.

29.RADULESCU, D., STROESCU BALCANGIU, A.E., PRICOP, C., et al. Rev. Chim. (Bucharest), 68, no. 1, 2017, p. 52-54.

30.MANEA, M., MARCU, D., PANTEA STOIAN, A., GAMAN, M.A., GAMAN, A.M., SOCEA, B., NEAGU, T.P., STANESCU, A.M.A., BRATU, O.G., DIACONU, C.C. Rev. Chim. (Bucharest), 69, no. 11, 2018, p. 41804184.

31.DIACONU, C.C., DEDIU, G.N., IANCU, M.A. Acta Cardiologica, 73, no. 6,2018, p. 511-517.

32.JUNUZOVIC, D., PRSTOJEVIC, J.K., HASANBEGOVIC, M., LEPARA, Z. Acta Inform Med., 22, no. 5, 2014, p. 309-314.

33.PARK, B.H., CHOI, H., KIM, J.B., CHANG, Y.S. Korean J Urol., 53, no. 1,2012 , p. 40-43.

34.TURK, C., KNOLL, T., PETRIK, A., et al. Members of the European Association of Urology (EAU) Guidelines Office. Guidelines on Urolithiasis; 28 $8^{\text {th }}$ Annual EAU Congress; Milano: 2013. pp. 41-51. EAU Guidelines.

35.ALBALA, D.M., ASSIMOS, D.G., CLAYMAN, R.V., et al. J Urol., 166, no. 6,2001, p. 2072-2080. 
36.LINGEMAN, J.E., SIEGEL, Y.I., STEELE, B., NYHUIS, A.W., WOODS, J.R. J Urol., 151, no. 3, 1994, p. 663-667.

37.MICHEL, M.S., TROJAN, L., RASWEILER, J.J. Eur Urol., 51, no. 4, 2007, p. 899-906.

38.UNSAL, A., RESORLU, B., ATMACA, A.F., et al. Urology, 79, no. 1, 2012, p. 55-60.

39.DEEM, S., DEFADE, B., MODAK, A., EMMETT, M., MARTINEZ, F., DAVALOS, J., Urology, 78, no. 4, 2011, p. 439-443.

40.GRASSO, M., CONLIN, M., BAGLEY, D., J Urol., 160, no. 2, 1998, p. 346-351.

41.GRASSO, M., FICAZZOLA, M., J Urol., 162, no. 6, 1999, p. 19041908.

42.SCARNECIU, I., MUNTEAN, I., SCARNECIU, C., SCARNECIU, V. Metalurgia International, 15, no. 11, 2010, p. 112-115.

43.BUMBU, A., PASCA, B., TIT, D. M., BUNGAU, S., BUMBU, G., Farmacia, 64, no. 3, 2016, p. 419.

44.BUMBU, B., NACER, K., BRATU, O., BERECHET, M., BUMBU, G, BUMBU, A., Proceedings of the 14th National Congress of Urogynecology and the National Conference of the Romanian Association for the Study of Pain, 2017, p. 90.

45.ABDEL-DAIM, M.M., ABO-EL-SOOUD, K., ALEYA, L., BUNGAU, S.G., NAJDA, A., SALUJA, R., Oxid. Med. Cell. Longev., 2018, 2018, ID 6276438. https://doi.org/10.1155/2018/6276438

46.ABDEL-DAIM, M.M., ZAKHARY, N.I., ALEYA, L., BUNGAU, S.G., BOHARA, R.A., SIDDIQI, N.J ., Oxid. Med. Cell. Longev., 2018, 2018, ID 2098123. https://doi.org/10.1155/2018/2098123

47.ABDEL-DAIM, M.M., ALEYA, L., EL-BIALY, B.E., ABUSHOUK A.I., ALKAHTANI, S., ALARIFI, S., ALKAHTANE, A.A., ALBASHER, G., ALI, D., RAFA S. ALMEER, AL-SULTAN, N.K., ALGHAMDI, J., ALAHMARI, A., BUNGAU, S.G., Environ. Sci. Pollut. Res., 26, no. 15, 2019, p. 15248. 48.ABDEL-DAIM, M.M., ABUSHOUK, A.I., DONIA, T., ALARIFI, S., ALKAHTANI, S., ALEYA, L., BUNGAU, S.G., Environ. Sci. Pollut. Res., 26, no. 13, 2019, p. 13502.

49.ABDEL-DAIM, M.M., AHMED, A., IJ AZ, J., ABUSHOUK, A.I., AHMED, H., NEGIDA, A., ALEYA, L., BUNGAU, S.G., Environ. Sci. Pollut. Res., 26, no. 8, 2019, p. 8080.

50.PAIK, M.L., WAINSTEIN, M.A., SPIRNAK, J.P., HAMPEL, N., RESNICK, M.I. J Urol., 159, no. 2, 1998, p. 374-379.

51.ROCCO, F., CASU, M., CARMIGNANI, L., et al. Br J Urol., 81, no. 6, 1998, p. 796-800.

52.SAMPAIO, F.J., ARAGAO, A.H. J Urol., 147, no. 2, 1992, p. 322-324. 53.SAMPAIO, F.J ., D'ANUNCIACAO, A.L., SILVA, E.C. J Endourol., 9, (suppl 1), S-631995, abstract 6-321.

54.RUGGERA, L., BELTRAMI, P., BALLARIO, R., et al. Int J Urol., 12, no. 6,2005 , p. 525-532.
55.PACE, K.T., TARIQ, N., DYER, S.J ., WEIR, M.J ., D'A HONEY, R.J., J Urol., 166, no. 6, 2001, p. 2065-2071.

56.NICELY, E.R., MAGGIO, M.I., KUHN, E.J., J Urol., 148, no. 3 Pt 2, 1992, p. 1036-1039.

57.GRAHAM, J.B., NELSON, J., J Urol., 152, no. 6 Pt 2, 1994, p. 2227. 58.KILICARSLAN, H., KAYNAK, Y., KORDAN, Y., et al. Urol J., 12, no. 2, 2015, p. 2065-2068.

59.RESORLU, B., et al. Urology, 79, no. 1, 2012, p. 61-66.

60.CHIONG, E., TAY, S.P.H., LI, M.K., SHEN, L., KAMARAJ, R., ESUVARANATHAN, K. Urology, 65, no. 6, 2005, p. 1070-1074.

61.SENER, N., IMAMOGLU, M.A., BAS, O., et al. Urolithiasis, 42, no. 2, 2014, p. 127-131.

62.PEARLE, M.S., LINGEMAN, J .E., LEVEILLEE, R., et al. J Urol., 173, no. 6, 2005, p. 2005-2009.

63.KUMAR, A., NADNDA, B., KUMAR, N. J Urol., 189, 2013, e750.

64.EL-NAHAS, A.R., IBRAHIM, H.M., YOUSSEF, R.F., SHEIR, K.Z. BJU International, 110, no. 6, 2012, p. 898-902.

65.YURUK, E., BINBAY, M., SARI, E., et al. J Urol., 183, no. 4, 2010, p. 1424-1428.

66.SCARNECIU, I., BRATU, O.G., COBELSCHI, C.P., et al. Rev Chim (Bucharest), 69, no. 12, 2018, p. 3406-3409.

67.SCARNECIU, I., LUPU, S., PRICOP, C., SCARNECIU, C. Pakistan Journal of Medical Sciences, 31, no. 3, 2015, p. 522-526.

68.PRICOP, C., DRAGOMIR, S., MARDARI, B., BARDAN, R., SCARNECIU, I., ORSOLYA, M. Archives of Biological Sciences, 66, no. 4, 2014, p. $1581-1584$.

69.ROCSOREANU, A., SZABETAY, C., CERNEA, D., MOTA, E. Arch Balk Med Union, 51, no. 4, 2017, p. 492-496.

70.LEE, S.W.H., CHAIYAKUNAPRUK, N., CHONG, H.Y., LIONG, M.L. BJU Int, 116, no. 2, 2015, p. 252-264.

71.SCARNECIU, I., ANDREI, C., SCARNECIU, C., et al. Urology J ournal, 15, no. 5, 2018, p. 297-299.

72.MONGA, M., BEST, S., VENKATESH, R., et al. J Urol., 176, no. 1, 2006, p. 137-141.

73.ABBOUDI, H., KHAN, M.S., GURU, K.A., et al. BJU Int., 114, no. 4, 2014, p. 617-629.

74.SKOLARIKOS, A., GRAVAS, S., LAGUNA, M.P., et al., BJU Int., 108, no. 6, 2011, p. 798-805.

75.RAMAN, J.D., PEARLE, M.S. Curr Opin Urol., 18, no. 2, 2008, p. $214-$ 219.

76.YEUNG, A.W.K., TZVETKOV, N., EL-TAWIL, O.S., BUNGAU, S.G., ABDEL-DAIM, M.M., ATANASOV, A.G., Oxid. Med. Cell. Longev., 2019, 2019, ID 8278454. https://doi.org/10.1155/2019/8278454

77.STANIMIR, M., CHIUTU, L.C., WESE, S., et al. Rom J Morphol Embryol, 57, (Supplement 2), 2016, p. 849-852.

Manuscript received: 11.07 .2019 